\title{
SINGLE EUROPEAN RAILWAY AREA AND THE PROBLEM OF RAIL INFRASTRUCTURE CHARGES - CASE STUDIES IN V4 COUNTRIES
}

\author{
Anna Dolinayová1,* , Igor Dömény ${ }^{1}, J^{1}$ Jansák$^{2}$, Peter Sulko ${ }^{3}$ \\ ${ }^{1}$ University of Zilina, Zilina, Slovakia \\ ${ }^{2}$ Integrated transport of the Central Bohemian Region, Prague, Czech Republic \\ ${ }^{3}$ Railways of the Slovak Republic, Bratislava, Slovakia \\ *E-mail of corresponding author: anna.dolinayova@fpedas.uniza.sk
}

\section{Resume}

This paper deals with the charging system and rail infrastructure fees use in V4 countries. The goal was to find out how the charges differ in terms of the train type, weight and distance traveled on different track categories. The charging principle for minimum access packages and for the access and services supplied in service facilities was investigated. Due to different technical, technological and other conditions for the rail infrastructure capacity utilization, the modeled situation was compared to the real one. This research shows differences between individual countries, both in the charging system and in the price for the rail infrastructure use (the prices were recalculated to $€$ and in the PPP-purchasing power parity). It is interesting that the differences are not only significant with regard to the category of track used and the train's weight (especially in the freight transport), but with regard to other factors, as well, in particular the type of train and price for the use of railway stations.

Available online: https://doi.org/10.26552/com.C.2021.4.A208-A222

\section{Article info}

Received 14 October 2020

Accepted 11 February 2021

Online 23 June 2021

\section{Keywords:}

access,

rail infrastructure, total and unit fees, passenger transport, freight transport, network statement

ISSN 1335-4205 (print version) ISSN 2585-7878 (online version)

\section{Introduction}

The major aim of the European transport policy is to achieve sustainable transport. The European Green Deal described the aims in the same areas such as alternative fuels, multimodal transport, the Single European Sky etc. Transport accounts for a quarter of the EU s GHG (greenhouse gasses) emission. To achieve a climate-neutral EU by 2050 requires among other a shift to more sustainable transport such as rail and inland waterways [1]. The rail transport is still considered as one of the ecological modes of transport, especially the use of electric traction. "Rail is still the most efficient solution for carrying freight across medium-long distances and it should therefore become more competitive" [2]. However, carriers and passenger will use the rail transport services if they are good quality and at an affordable price, which means that the railway transport would be competitive and effective. The European Union adopted a number of directives and regulations to achieve this goal, which described in the railway packages, the main goal of the Fourth Railway Package is a single European railway area. This Package comprises two "pillars" which have been negotiated largely in parallel, "technical pillar" and "market pillar". One of the goals of the Fourth Railway Package is to liberalize the rail passenger market and to remove barriers for interoperability. The development of the railway infrastructure and improvement of quality of the rail passenger services are the key priorities in promotion of a sustainable transport and mobility system in Europe [3].

The rail infrastructure charges are one of the main conditions to achieving a single European railway area. The principles of the rail infrastructure charges are defined by legislative framework of the European Parliament, Council and Commission mainly in Directive 2012/34/EU of the European Parliament and of the Council of 21 November 2012 establishing a single European railway area. Chapter IV of this Directive is focused on charges for the use of railway infrastructure and allocation of the railway infrastructure capacity. Infrastructure managers must publish the content of network statement free of charge in electronic format on their webs in at least two official European Union languages [4]. Directive 2012/34/EU has been amended by Directive (EU) 2016/2370 but this amendment did not affect the charging scheme neither the infrastructure capacity allocation model (except for the timing of the capacity allocation process).

Although the Directive describes the general principles and sets-out the basic framework for the rail infrastructure charging, each EU country uses a different rail infrastructure charging system. As 
a result, any carrier wishing to use the infrastructure of one or more countries must become very familiar with the specific charging systems of each country. From the viewpoint of railway undertakings, this is a very lengthy process.

This study compares the rail infrastructure charges for the specific freight and passenger trains in the different track categories in V4 countries. The V4 countries were chosen because the V4 regional cooperation is also successfully developing in the current period, mainly in the sectoral policies, such as economy, digitalization, infrastructure and innovation. In addition, authors have dealt with several projects funded by the International Visegrad Fund. For the relevance of the comparison, authors have recalculated the prices in the individual countries according to purchasing power parities. The presented case studies were modeled since it is not possible to achieve exactly the same conditions in all the countries in practice.

\section{Literature review}

A number of papers that dealt with rail infrastructure costs from a different point of view were studied. The marginal maintenance costs of the rail infrastructure have been researched very often. Some authors researched this issue from the traffic point of view [5-8]. Calvo et al. researched the impact of the train type (short-distance trains, long-distance trains and freight trains) to maintenance and renewal costs [9]. Odolinski estimate the impact of axle loads on rail infrastructure maintenance costs [10]. Smith et al. estimated the relative marginal cost of different vehicles types running on the rail infrastructure [11].

Appropriate access charges are one of the conditions for guaranteeing fair competition in the rail sector [12]. Infrastructure managers in European Countries use different railway infrastructure tariff system principles to set the price for using a rail network such as marginal cost of a train running in the network, recovering the marginal costs plus a mark-up, recovering the full costs or recovering the full costs minus a State subsidy [13]. Nash researched the rail infrastructure charges in 23 European countries. He stated that a wide variety of both structure and level of charges existed [14].

Some authors researched the different factors or processes which influence rail infrastructure costs or charges. Some of these factors can be influenced by the rail infrastructure managers, some by the rail freight or passenger operators. The rail network capacity utilization can influence those infrastructure charges and simultaneous optimal rail infrastructure capacity utilization is necessary for terms of a liberalized access to the infrastructure [15]. The lower rail infrastructure charges can be achieved by using modern wagon types [16]. Ober et al. investigated rail infrastructure charges with respect to vehicles' characteristics [17]. Savelsberg and Talebian researched a proposed access charge regime aimed at motivating the operators to use longer train configurations [18].

In most articles, authors have examined the rail infrastructure charges or charging system in individual countries. Stendard et al. used an econometric approach to estimate the costs function and marginal costs in regional lines, which constitute the basis for the railway charges in Slovenia [19]. Trampish explained the financing system of the German railway sector, especially due to the control- and supervision duties of Bundesnetzagentur, which is under the new rail regulation law in charge of controlling the charging system of infrastructure managers [20]. Abramovic dealt with the calculating infrastructure charges and considered problems with the way in which this is dealt with in a case study in Croatia [21]. Alvarez-SanJaime et al. analyzed access charges for the use of the rail infrastructure and other factors to the introduction of on-track competition in High Speed Rail lines in Spain [22]. Talebian et al. studied a rail track access charging policy proposed by the Australian Rail Track Corporation, in which a discount on access charges is offered if above-rail operators employ the train with a particular length, which results in the efficient use of a train path [23]. Bugarinovic et al. developed a model for the access charges based on the analytic network process approach. Their model presents the objectives of the identified stakeholders through the established criteria from three different perspectives: the government influence, railway market environment, network use efficiency and used it in the Serbian Railways case study [24]. Crozet and Chassagne explain why, in terms of welfare and subject to some conditions, high rail access charges are economically justified. They have been estimating the market entry conditions for the high speed rail in France for a competitor [25]. Nikolova evaluated the pricing principles and approaches to charging infrastructure costs in Bulgaria [26].

As can be seen in this literature review, authors mainly investigated the rail infrastructure charges from two points of view: comparison of the principles and methods of rail infrastructure charges and description of the rail infrastructure charges in individual countries. Authors did not find scientific papers comparing the rail infrastructure charges in V4 countries (expect [27]). This issue is mentioned marginally in scientific papers dealing with the rail competition, for example in [28-30]. There are very few articles that compare the rail infrastructure charges for certain transportation in several countries.

\section{Methodology}

The rail infrastructure charging system is described in Network Statement (NS) in each of the EU countries. The NS have a uniform structure, most often with the 
following chapters:

- general information

- access conditions

- infrastructure

- infrastructure capacity allocation

- services

- charges.

In this study, a basic formula for calculating the charges for minimum access packages was used. In the Slovak Republic the formula is [31]:

$$
\begin{aligned}
& U_{m p}=\sum_{i=1}^{n} U_{1 i} * V 1_{i}+\sum_{i=1}^{n} U_{2 i} * V 1_{i}+ \\
& +\sum_{i=1}^{n} \frac{U_{3 i} * V 2_{i}}{1000} * k_{e}+\sum_{i=1}^{n} \frac{U_{4 i} * V 2}{1000},
\end{aligned}
$$

where:

$U_{m p}$ charges for the minimum access packages,

$U_{1 i}$ maximum charges for ordering and allocating infrastructure capacity,

$U_{2 i}$ maximum charges for the traffic management and organization,

$U_{3 i}$ maximum charges for ensuring railway infrastructure serviceability,

$U_{4 i}$ maximum charge for use of the electrical supply equipment to supply traction current,

$V 1_{i}$ train $\mathrm{km}$ performances in the $i$-tracks category,

$V 2_{i}$ gross ton $\mathrm{km}$ performances in the $i$-tracks category,

$k_{e}$ coefficient that takes into account the diesel trains running on electrified tracks.

Besides the minimum access charges described in Equation (1), the carriers must pay charges for the access and the services supplied in service facilities [31]:

- charges for access to passenger stations, its premises and facilities, including the facilities for travel related information

- charges for access to a location for ticketing services at passenger stations

- charges for access to train formation stations and train formation equipment, including the shunting facilities and to freight terminals solely operated by the Railways of the Slovak Republic - ZSR (Zeleznice Slovenskej Republiky / Railways of the Slovak Republic)

- charge for the access to storage tracks.

The Czech Republic use different rail infrastructure charging systems, which is focused in the three following formulas [32]:

$$
C=K_{1}+K_{2} * D_{t}+K_{3} * P_{d j},
$$

where:

$C$ railway capacity allocation price,

$K_{1}$ rate for processing and planning of the timetable and allocating railway capacity,

$K_{2}$ rate for designing a train route,

$K_{3}$ daily rate for a train route allocation,

$D_{t}$ distance of the allocated route between the departure and final points of the route on railway network, $P_{d j}$ number of days for which the route is allocated.
$C_{s}=L * Z * K * P_{x} * S_{1} * S_{2}$,

where:

$C_{s}$ costs of using the railway by one sub-train,

$L$ length of the sub-train movement,

$Z$ basic price per 1 train $\mathrm{km}$,

$K$ track category coefficient,

$P_{x}$ product factor $\mathrm{P}_{1}$ to $\mathrm{P}_{5}$,

$S_{1}, S_{2}$ specific factors.

$C_{P K}=\sum_{n=11}^{15}\left(Z_{n}^{p k} * m_{p k} * N_{z n}\right)$

where:

$C^{P K}$ the costs of using the access roads for passengers on a passenger train,

$z_{n}^{p k}$ basic price for one scheduled stop of a passenger train for boarding and/or disembarking of passengers at railway stations and stops of category " $n$ ",

$m_{p k}$ train weight for calculating the cost of using passenger access services on a passenger train,

$N_{z n}$ the planned number of stops of a passenger train for boarding and / or disembarking passengers at " $n$ " category railway stations and stops.

The minimum access package described in Equation (2) and (3) includes the costs of the allocation of rail capacity and the price of the infrastructure manager for the use of track by running the train. The price of using access roads for passengers on a passenger train (Equation (4)) is the price for services provided within the minimum scope and content of services and forms a separate component of the regulated price for the use of track by train [32].

The rail infrastructure charges (minimal access packages) in Hungary are based on charges for ensuring the train path, running of trains, use of catenary, use of station for the passenger and freight trains. Those charges are described using the following formulas by Network Statement MAV (Magyar Allamvasutak Hungarian State Railways), 2020 [33]:

$E_{v t}=P_{t r k m} * S_{t k m}$

where:

$E_{v t}$ ensuring the train path,

$P_{\text {trkm }}$ performances in train $\mathrm{km}$,

$R_{e}$ rate of insurance per train $\mathrm{km}$.

$R=\sum_{i=1}^{n} P_{i t k m} * R_{r t k m}+P_{g r t k m} * R_{g r t k m}+P_{t k m} * R_{e}$,

where:

$R \quad$ running of trains,

$P_{\text {trkm }}$ performances in train $\mathrm{km}$ in the $i$-line section category,

$R_{r} \quad$ running rate per train $\mathrm{km}$,

$P_{\text {grtkm }}$ performances in gross ton $\mathrm{km}$ in the $i$-line section category,

$R_{\text {grtkm }}$ running rate per gross ton $\mathrm{km}$,

$R_{e} \quad$ catenary use rate. 


$$
P_{S t-P T}=\sum_{i=1}^{n} N_{i}^{P T} * R_{i}^{S t}+\sum_{i=1}^{n} N_{i}^{P T-o / d} * R_{i}^{P T-o / d}
$$

where:

$P_{S t-P T} \quad$ station use charges for passenger trains,

$N_{i}^{P T} \quad$ number of factual passenger train stopping at stations in the $i$-station category,

$R_{i}^{S t} \quad$ fee for use of stations for stopping the passenger trains,

$N_{i}^{P T-o / d}$ number of origin/destination stations by the passenger trains,

$R_{i}^{\text {PT-o/d }}$ fee for use of origin/destination stations by the passenger trains.

$$
P_{S t-F T}=\sum_{i=1}^{n} N_{i}^{F T} * R_{i}^{S t-F T},
$$

where:

$P_{S t-F T} \quad$ charges for station use for freight trains,

$N_{i}^{F T}$ number of factual freight train stoppings at stations in $i$-station category,

$R_{i}^{S t-F T}$ fee for station use for stopping the freight trains.

Hungary has two infrastructure managers - MAV

Zrt and GYSEV Zrt (Gyor-Sopron-Ebenfurth Railway).

Both have the same charging principle described in Equations (5) - (8), only fees for individual charging are different.

The rail infrastructure charges in Poland are based on train and gross train km; unlike the Czech Republic and Hungary Poland does not take into account type of passenger and freight trains similar to Slovakia. The basic principle of charges by Annex 12 of Network Statement is described by the following Formula [34]:

$$
\begin{aligned}
& C h_{S F}=R_{M K} *\left(W_{T C} * P_{t r k m}+S_{M P B} * W_{w} * P_{t r k m}\right)+ \\
& +R_{E} * P_{t r k m} .
\end{aligned}
$$

where:

$C h_{S F}$ charges for using the railway infrastructure standard fees,

$R_{M K}$ average rate according to the train weight and railway line category,

$W_{T C}$ rate factors according to the railway line category,

$W_{w}$ rate factors according to total planned train gross weight,

$R_{E} \quad$ sub rate varying according to traction for trains and shunting operations based on electric traction,

$P_{\text {trkm }}$ performances in train $\mathrm{km}$.

Besides the charges described in Equation (9), the rail freight and passenger carriers must pay a handling fee for capacity allocation applications.

The fundamental principle of the rail infrastructure charges, under the minimal access packages, are described in the previous formulas. More detailed information, as well as fees are given in the individual NS on the website of each rail infrastructure manager.

The methodology for calculating the rail infrastructure charges in the V4 countries is based on the assumption that the transport process is carried out under the same conditions in all the countries (the same trainset, the same gross weight of locomotive and wagons, the use of railway stations and railway lines of the same category, etc.). This is the basic condition for a relevant comparison of the level of the rail infrastructure charges in each country.

As the rail infrastructure charges for the minimum access packages and railway access to services facilities fall into the category of regulated prices, infrastructure managers must publish them on their websites. Given that this is a number of prices depending on various factors, Table 1 provides an overview of prices for passenger trains for the $1^{\text {st }}$ or the highest railway line category and also for the highest railway station category.

All the fees were recalculated to euros according to the official exchange rates and then those fees were recalculated according to the purchasing power parity (PPP) for individual countries. Table 2 shows the data used.

Calculation of the rail infrastructure charges was realized for the five alternatives:

- rail passenger transport:

- express train (Ex) in the first or comparable railway line category - electrified

- regional train in the second or comparable line category - non electrified

- regional train in the third or comparable line category - non electrified

- rail freight transport:

- through freight train in the first or comparable railway line category - electrified

- container train in the first or comparable railway line category - electrified.

The calculation of the rail infrastructure charges was realized in the spreadsheet program MS Excel based on Equations (1) - (9) by use of prices from the Network statements of the V4 countries. More detailed information about the trains parameters and other factors are described in the next section. The total fees of the rail infrastructure charges were modelled due to distance to better present the differences.

\section{Results - case studies in the V4 countries}

The change in the rail infrastructure access fees was investigated with respect to various distances in different situations in the rail passenger and freight transport. The calculation is based on the NS and individual Annexes of NS, regarding relating to price or specific charging conditions for timetable 2020/2021. The rail infrastructure charges for minimum access packages and railway access to services facilities, were compared. Charges of additional and ancillary services were not taken into account because those charges are very different and depend on a number of different factors. In 
Table 1 Selected prices of the rail infrastructure charges for passenger trains

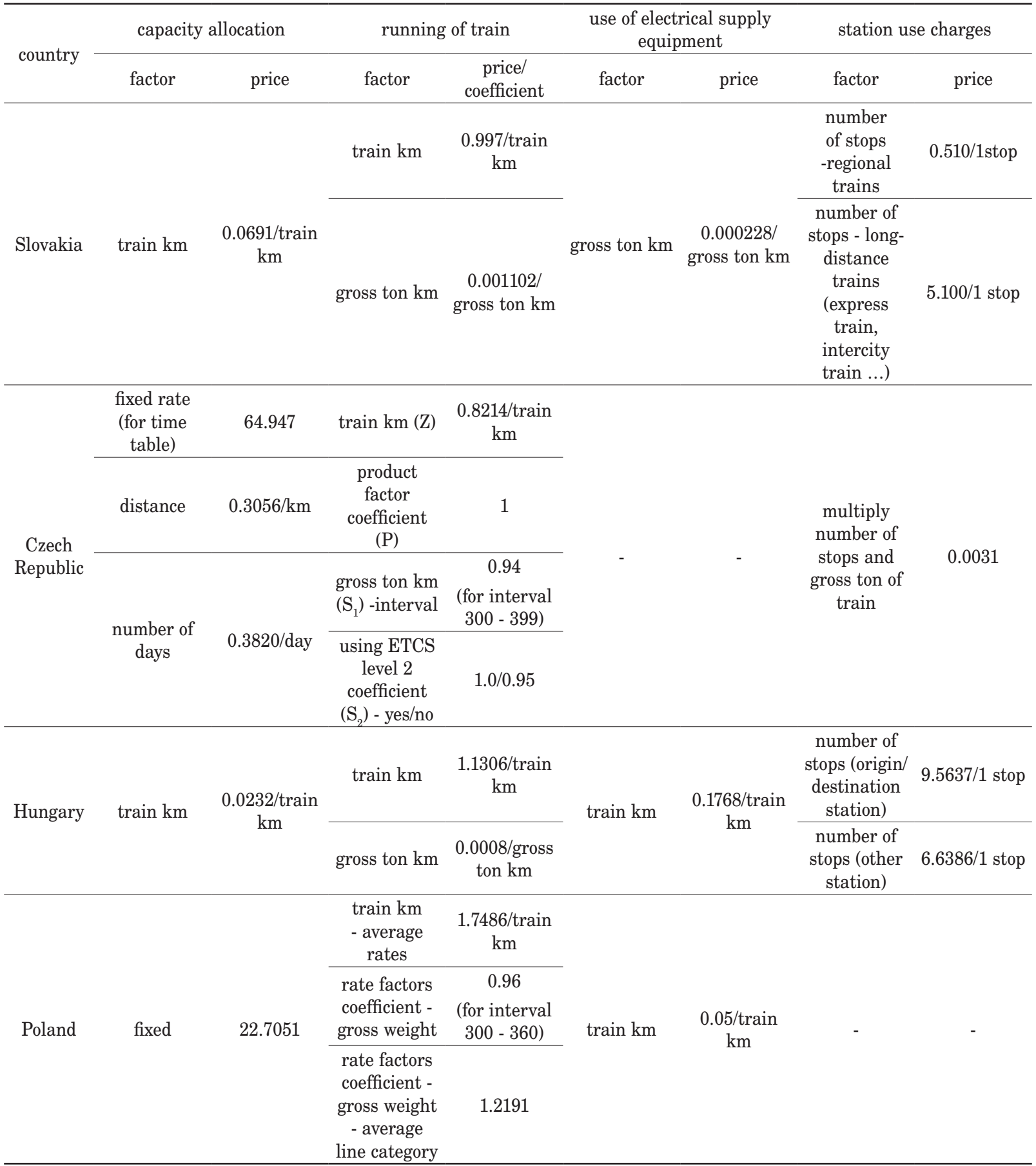

Note: All the prices are listed in $€$ without VAT

Based on Network Statements of each country [31-34]

Table 2 Data of exchange rates and PPP

\begin{tabular}{cccc}
\hline country & PPP & \multicolumn{2}{c}{ exchange rate as of 01.08.2020 } \\
\hline European Union & 100 & & - \\
Czech Republic & 73.4 & 26.175 & CZK per $1 €$ \\
Hungary & 64.5 & 344.95 & HUF per $1 €$ \\
Poland & 59.5 & 4.4034 & PLN per $1 €$ \\
Slovakia & 79.7 & & - \\
\hline
\end{tabular}

Source: [35-36] 
Table 3 The passenger train parameters

\begin{tabular}{|c|c|c|c|c|c|c|c|}
\hline & $\begin{array}{l}\text { type of } \\
\text { locomotive }\end{array}$ & $\begin{array}{l}\text { weight of } \\
\text { locomotive } \\
\text { HKV (t) }\end{array}$ & $\begin{array}{l}\text { type of } \\
\text { wagon }\end{array}$ & $\begin{array}{l}\text { number of } \\
\text { wagons }\end{array}$ & weight (t) & $\begin{array}{c}\text { capacity } \\
\text { (passengers) }\end{array}$ & $\begin{array}{l}\text { total weight } \\
\text { of trainset }(\mathrm{t})\end{array}$ \\
\hline \multirow{3}{*}{ express train } & \multirow{3}{*}{$\begin{array}{l}193 \text { (Siemens } \\
\text { Vectron) }\end{array}$} & \multirow{3}{*}{89} & WRmz817 & 1 & 54 & - & \multirow{3}{*}{347.84} \\
\hline & & & Ampz143 & 1 & 49 & 58 & \\
\hline & & & Bdmpee233 & 3 & 44 & 80 & \\
\hline regional train & $\begin{array}{c}\text { Diesel } \\
\text { Multiple Unit } \\
643\end{array}$ & - & - & - & 57 & 137 & 67.96 \\
\hline regional train & $\begin{array}{c}\text { Diesel } \\
\text { Multiple Unit } \\
861\end{array}$ & - & - & - & 120 & 291 & 143.28 \\
\hline
\end{tabular}

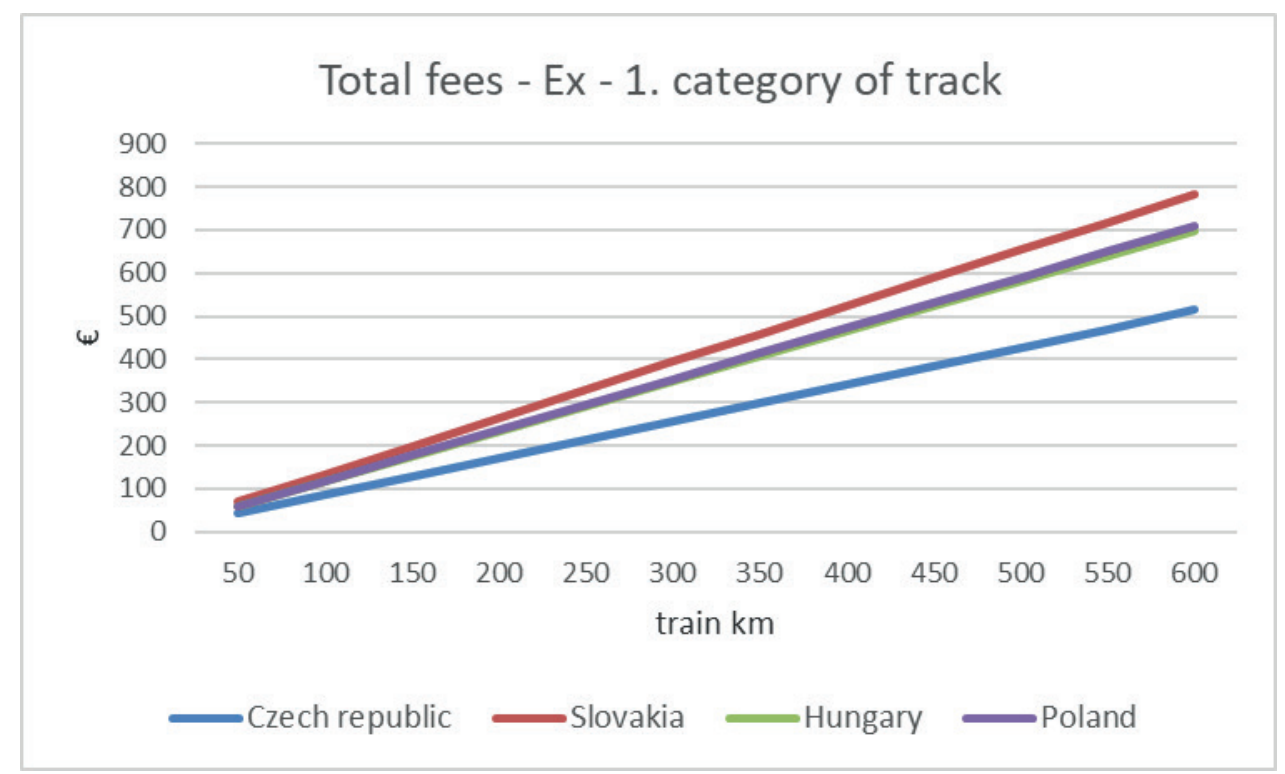

Figure 1 Total fees of the rail infrastructure access for an express train in the first track category

addition, the rates for these services are commercial and the resulting prices depend on the contract between the manager and the carrier.

\subsection{The passenger transport}

With regard to passenger transport the express train in the first or higher track category (by NS of individual countries) and regional trains $(\mathrm{Re})$ on second and third or comparable track categories were taken into account. Table 3 shows train switching and other parameters needed for calculation of fees.

Calculation is based on these premises:

- type of train is the same in all the V4 countries although this is sometimes not realistically possible (e.g. due to the technical parameters of wagons, locomotives and trains)

- an express train stops every $50 \mathrm{~km}$ on average in the $\mathrm{A}$ or the first station category, a passenger train stops on average every $5 \mathrm{~km}$ in the second and third or comparable station category

- trains do not use the track for storage.

The results of the total and unit fees for an Express train in the first track category are shown in Figure 1 and Figure 2.

As can be seen in Figure 1, Slovakia has the highest fees for use of the railway infrastructure capacity. In Poland, compared to other V4 countries, the base rate, which depends on the train $\mathrm{km}$, is almost twice as large (e.g. in the Czech Republic it is $21.50 \mathrm{CZK}$ - $€ 0.8214$ per train $\mathrm{km}$, in Poland is $7.7 \mathrm{PLN}-€ 1.7486$ per train $\mathrm{km}$ ), but there is no charge for use of the electrical supply equipment to supply traction current of Poland Unit fees are the same for any train $\mathrm{km}$ in Poland. It is caused by the system of the rail infrastructure charges, which has no special price for access to services facilities in Poland. Differences between Slovakia and Hungary are not great, for example total fees for 200 train $\mathrm{km}$ in Slovakia is $€ 264$ and in Hungary $€ 234$. The Czech Republic has the lower fees (in the modeled conditions), approximately $30 \%$ compared to Slovakia and Hungary.

The system of the rail infrastructure charges is the same for Regional trains and Express trains in all the V4 countries. The differences are only in prices, no V4 countries take into account market segmentation in the rail passenger transport. Figures 3 and 4 show results of the rail infrastructure charges, calculated for a regional 


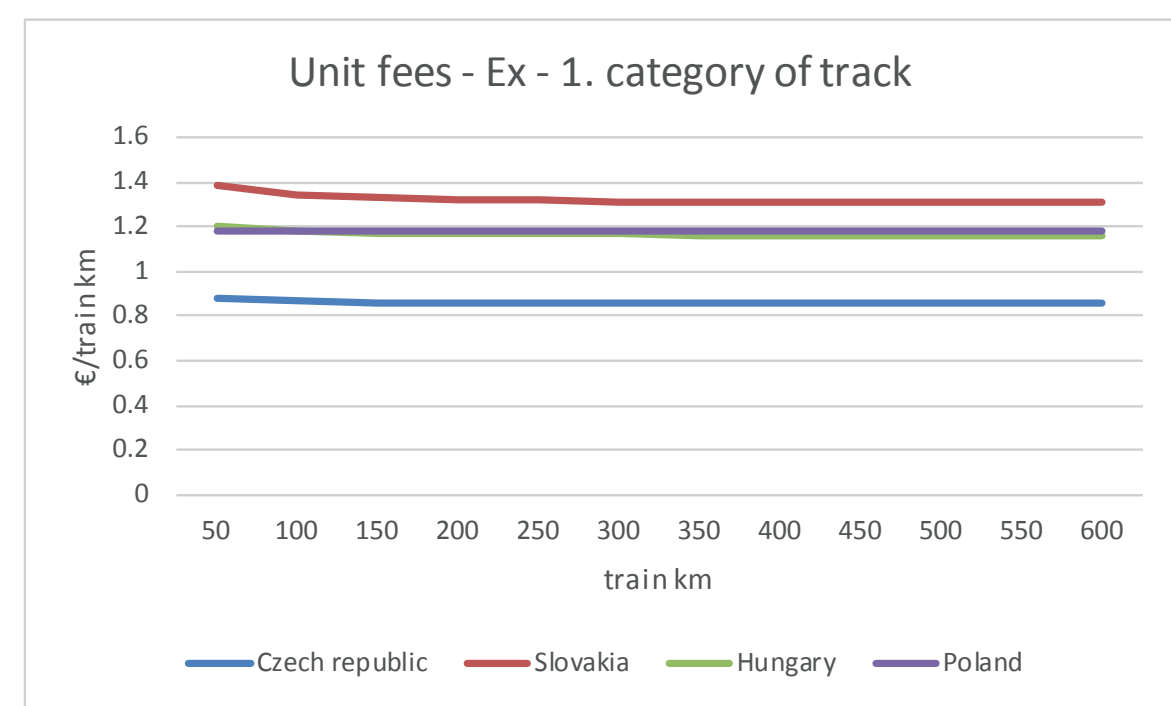

Figure 2 Unit fees of the rail infrastructure access for an express train in the first track category

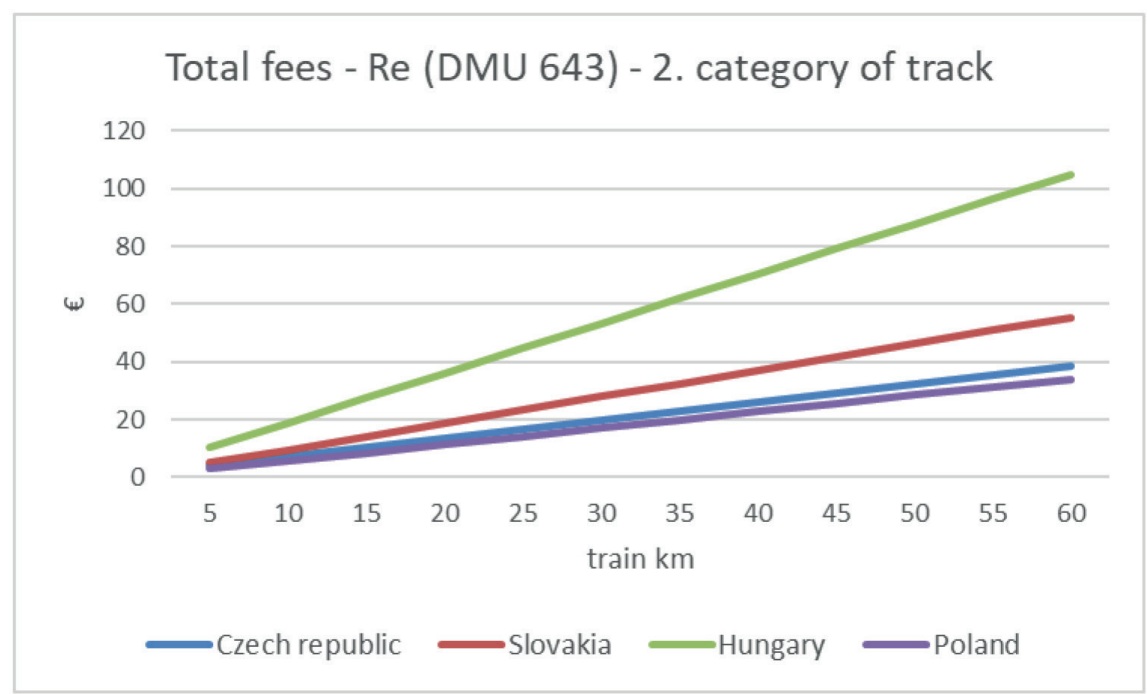

Figure 3 Total fees for the rail infrastructure access for a regional train (DMU 643) in the second track category

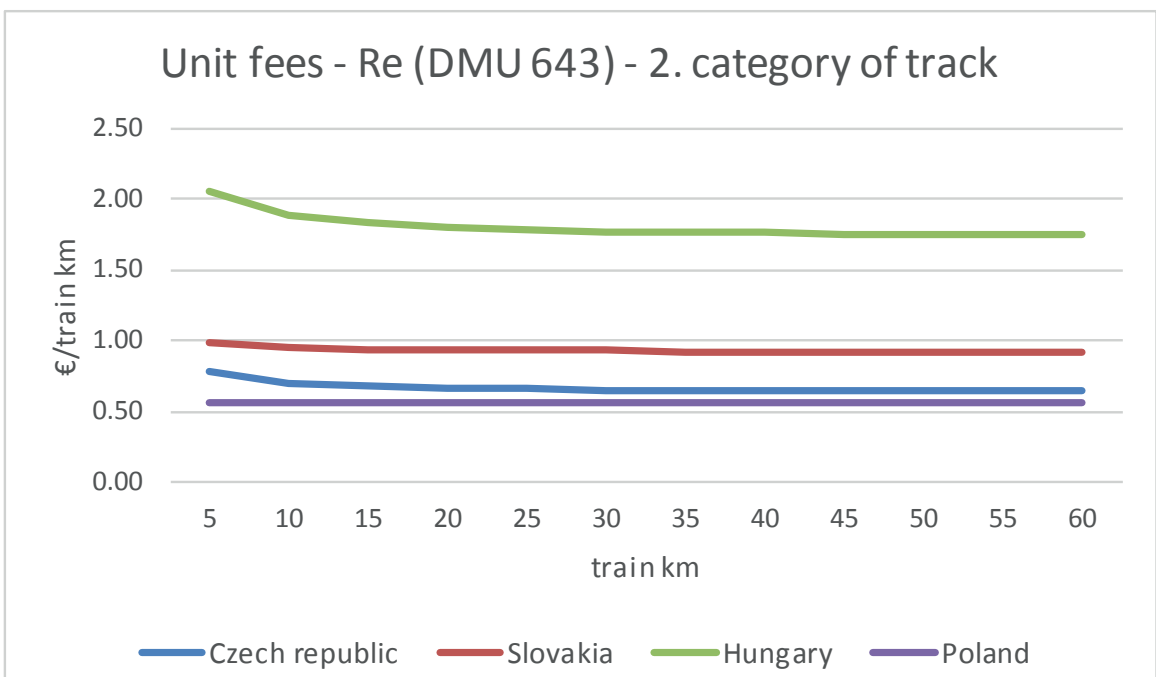

Figure 4 Unit fees for the rail infrastructure access for a regional train (DMU 643) in the second track category 


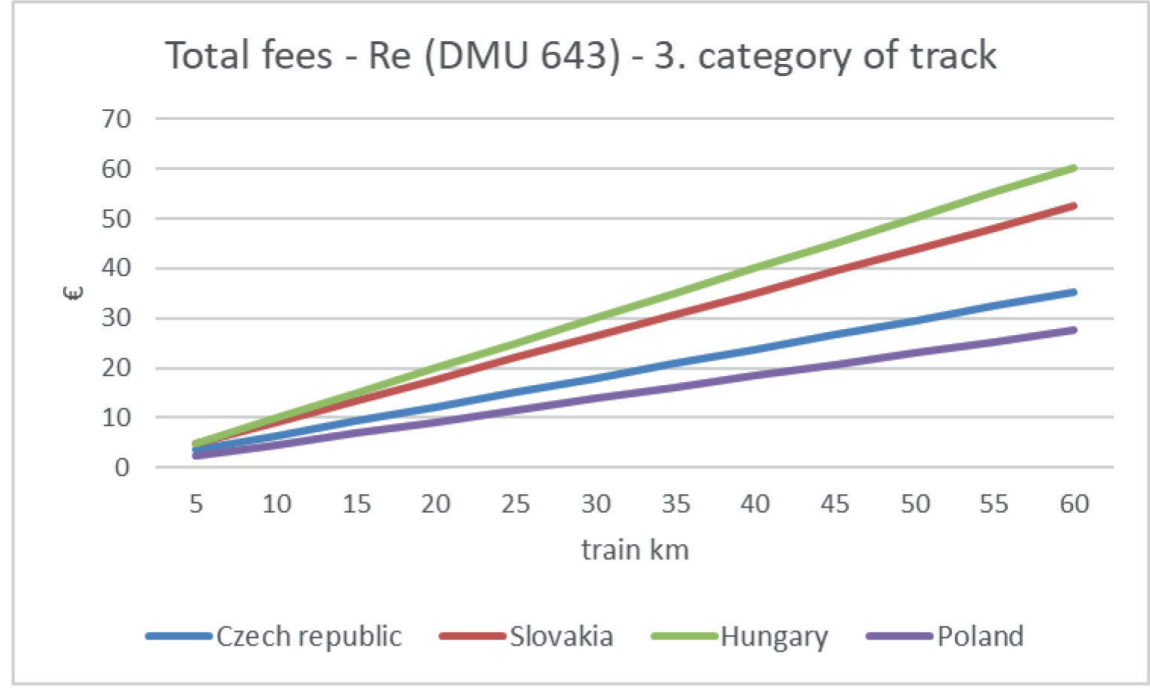

Figure 5 Total fees of the rail infrastructure access for regional trains (DMU 643) in the third track category

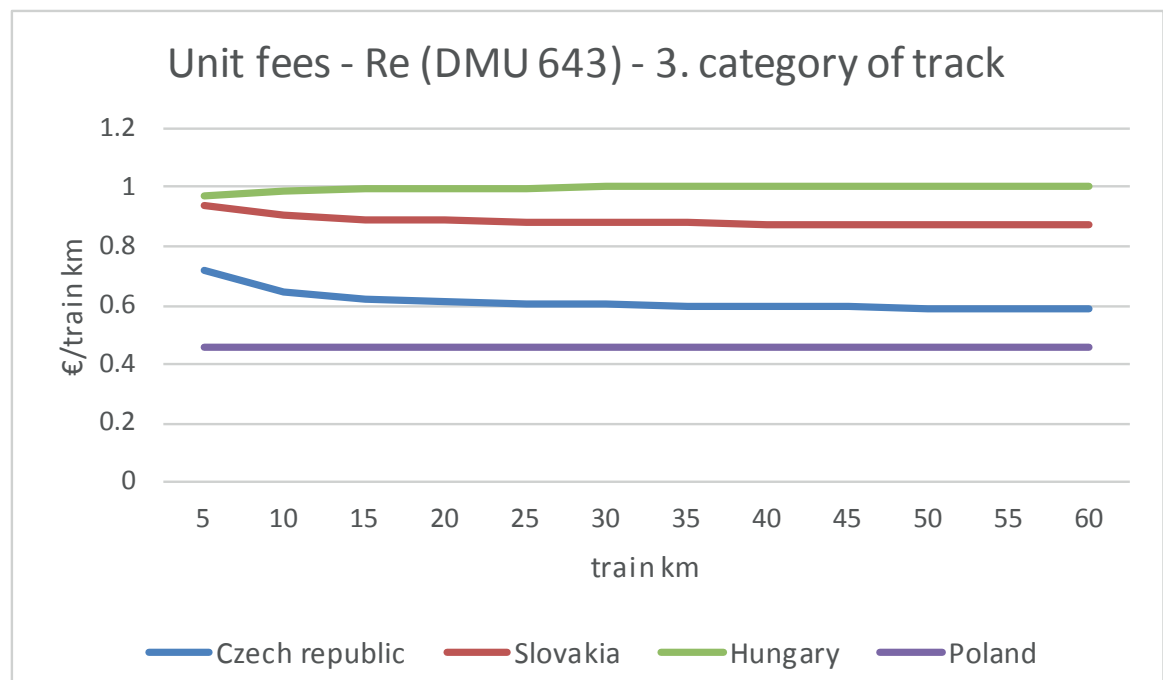

Figure 6 Unit fees of the rail infrastructure access for regional trains (DMU 643) in the third track category

train (train switching - DMU 643) in the second track category and Figures 5 and 6 show the results in the third track category.

When comparing Figures 3 and 5 one can see differences in the price level of the second and third track categories. While in the Czech Republic and Poland the total fees are approximately the same in the second track category (differences is only $4.425 €$ for $60 \mathrm{~km}$ distance), in the third track category difference is $7.735 €$ for $60 \mathrm{~km}$ distance. The total fees are very different in the second and third track categories in Hungary. If one compares Hungary (the highest total fees) to Poland (the lowest total fees), in the second category the difference is $70.958 €$, but in the third it is only $32.586 €$. In the case of passenger trains, which run over short distances, station charges were much more pronounced in the rail infrastructure charges. In Tables 4 and 5 the fees in the 2. and 3. track category are compared, divided into the minimum access packages (MAP) and access to services facilities (ASF).
In Poland, the fee for access to services' facilities is paid only for services, which are supplied (for example shunting) mainly for freight trains. Therefore, this fee is not listed in the Table 4 and 5 to make it comparable to other countries.

As can be seen in Tables 4 and 5, in the Czech Republic the price level for the minimum access packages is approximately the same for the second and third track categories, the price level for the third track category is approximately 58\% lower compared to the second category in Hungary. Access to services facilities fees is also lower in the third track category.

Here is also investigated how the fees would change if the train shifting changed. Figures 7 and 8 show the results for Regional train (train switching - DMU 861) in the second track category.

Due to the fact that the change of train switching affects only the part of the fees that are dependent on the gross ton $\mathrm{km}$, there is no significant differences 
Table 4 Total fees of the minimum access packages and access to services facilities in the 2. track category

\begin{tabular}{cccccccc}
\hline & \multicolumn{2}{c}{ Czech Republic } & \multicolumn{2}{c}{ Slovakia } & \multicolumn{3}{c}{ Hungary } \\
\hline train km & MAP & ASF & MAP & ASF & MAP & ASF & MAP \\
\hline 5 & 3.187 & 0.726 & 4.203 & 0.765 & 3.434 & 6.829 & 2.235 \\
10 & 5.963 & 1.089 & 8.407 & 1.148 & 6.869 & 12.004 & 5.669 \\
15 & 8.739 & 1.452 & 12.610 & 1.530 & 10.303 & 17.180 & 8.504 \\
20 & 11.515 & 1.815 & 16.814 & 1.913 & 13.738 & 22.356 & 11.339 \\
25 & 14.291 & 2.178 & 21.017 & 2.295 & 17.172 & 27.531 & 14.173 \\
30 & 17.067 & 2.540 & 25.221 & 2.678 & 20.606 & 32.707 & 17.008 \\
35 & 19.843 & 2.903 & 29.424 & 3.060 & 24.041 & 37883 & 19.843 \\
40 & 22.619 & 3.266 & 33.628 & 3.443 & 27.475 & 43.059 & 22.677 \\
45 & 25.395 & 3.629 & 37.831 & 3.826 & 30.910 & 48.234 & 25.512 \\
50 & 28.172 & 3.992 & 42.035 & 4.208 & 34.344 & 53.410 & 28.347 \\
55 & 30.948 & 4.355 & 46.238 & 4.591 & 37.779 & 58.586 & 31.181 \\
60 & 33.724 & 4.718 & 50.442 & 4.973 & 41.213 & 63.761 & 34.016 \\
\hline
\end{tabular}

Table 5 Total fees of the minimum access packages and access to services facilities in the 3. track category

\begin{tabular}{ccccccccc}
\hline & \multicolumn{2}{c}{ Czech Republic } & \multicolumn{2}{c}{ Slovakia } & \multicolumn{3}{c}{ Hungary } & \multicolumn{2}{c}{ Poland } \\
\hline train km & MAP & ASF & MAP & ASF & MAP & ASF & MAP \\
\hline 5 & 3.010 & 0.581 & 3.973 & 0.733 & 1.443 & 3.414 & 2.303 \\
10 & 5.609 & 0.871 & 7.945 & 1.100 & 2.886 & 7.004 & 4.606 \\
15 & 8.207 & 1.161 & 11.918 & 1.466 & 4.329 & 10.594 & 6.909 \\
20 & 10.806 & 1.452 & 15.891 & 1.833 & 5.772 & 14.185 & 9.212 \\
25 & 13.405 & 1.742 & 19.864 & 2.200 & 7.215 & 17.775 & 11.515 \\
30 & 16.004 & 2.032 & 23.836 & 2.566 & 8.658 & 21.365 & 13.818 \\
35 & 18.603 & 2.323 & 27.809 & 2.933 & 10.101 & 24.955 & 16.121 \\
40 & 21.201 & 2.613 & 31.782 & 3.300 & 11.544 & 28.545 & 18.424 \\
45 & 23.800 & 2.903 & 35.755 & 3.666 & 12.987 & 32.135 & 20.727 \\
50 & 26.399 & 3.194 & 39.727 & 4.033 & 14.430 & 35.725 & 23.030 \\
55 & 28.98 & 3.484 & 43.700 & 4.399 & 15.873 & 39.315 & 25.333 \\
60 & 31.97 & 3.774 & 47.673 & 4.766 & 17.316 & 42.905 & 27.586 \\
\hline
\end{tabular}

between countries. For example, if we take into account the distance of $60 \mathrm{~km}$, the difference in the fee between the Slovak Republic and Czech Republic is $16.69 €$ for DMU 861 and 16.97 for DMU 643. Comparing Figures 3 and 7 , it can be seen that the differences between countries are minimal.

\subsection{The freight transport}

The comparison of the rail infrastructure charges for the freight transport is more complicated than for the passenger transport. This is because the final price can be affected by several different factors, such as the division of the freight transport into several different categories that have their own rates or coefficients affecting the final price (standard freight trains, combined transport trains, individual wagon consignments), different prices for different railway line categories or route ordering regime (up to annual timetable, ad-hoc). In addition, not all the infrastructure managers use the same freight transport distribution factors to calculate fees. Therefore, only 2 types of a freight train - through freight train (Figure 9 and 10) and container train (Figure 11 and 12) in the first track category, were compared.

Calculation is based on these premises:

- gross ton weight of a through freight train is 1,700 tons and container train 1,000 tons,

- both trains stop only in the originating and destination stations of a train,

- both originating and destination stations are the highest category,

- trains do not use track for storage,

- trains are planned in the annual timetable no ad-hoc (Hungary and Poland do not have a special price level for ordering and allocating infrastructure capacity for ad-hoc train). 


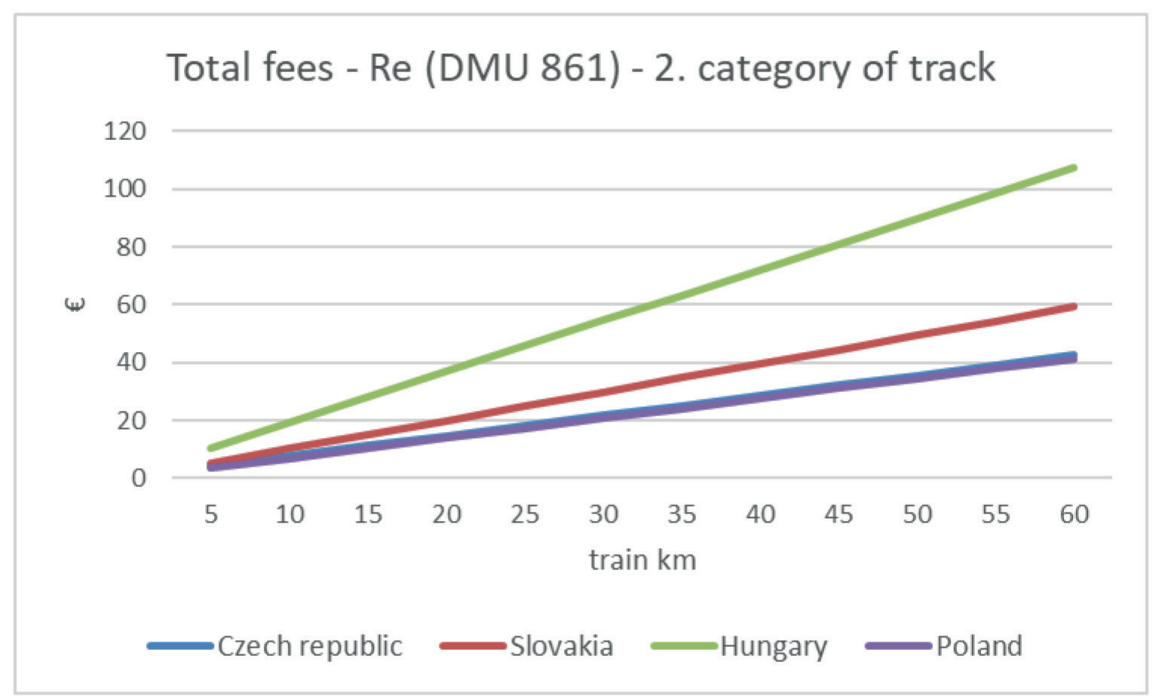

Figure 7 Total fees for the rail infrastructure access for a Regional train (DMU 861) in the second track category

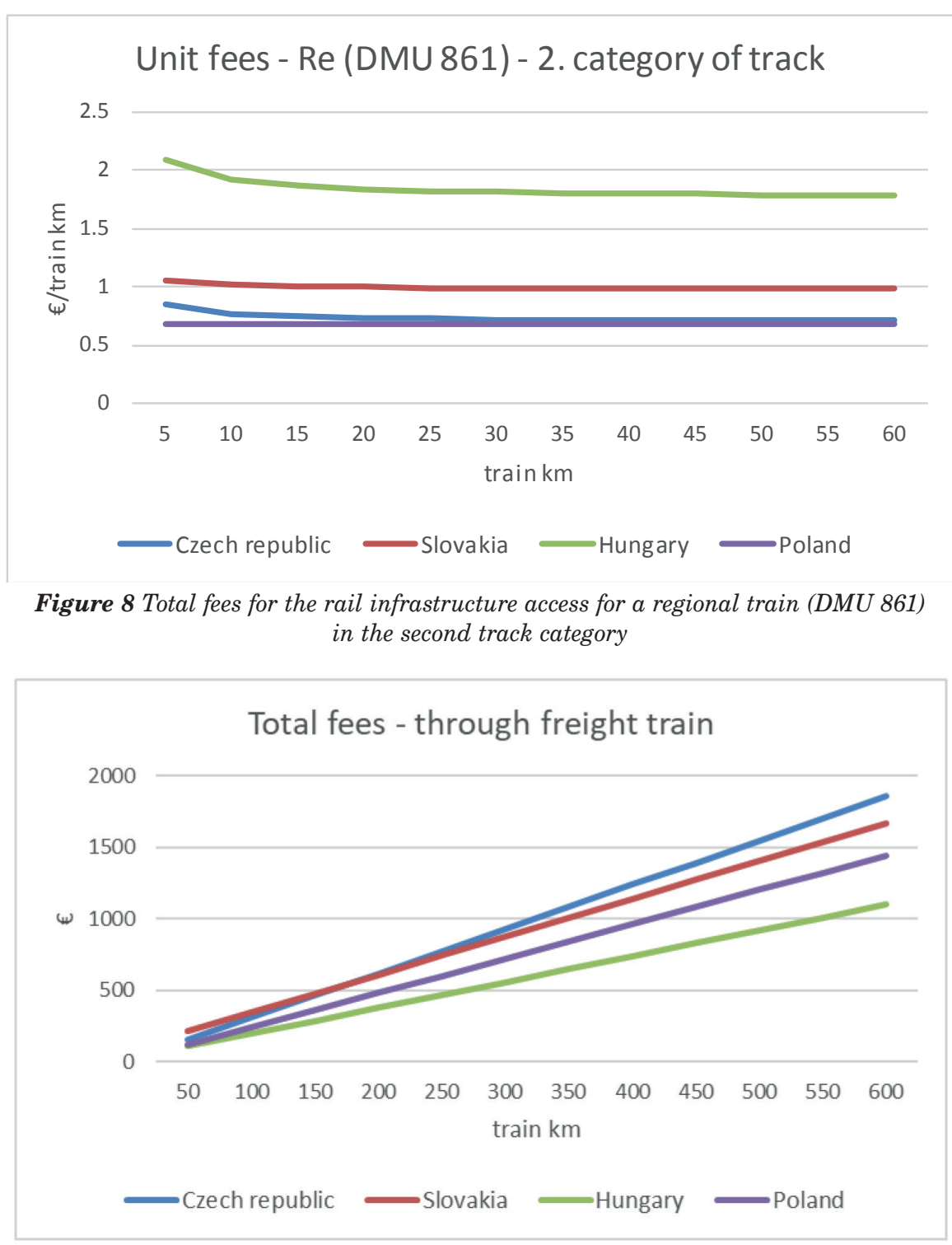

Figure 9 Total fees for the rail infrastructure access for a through freight train in the first track category 


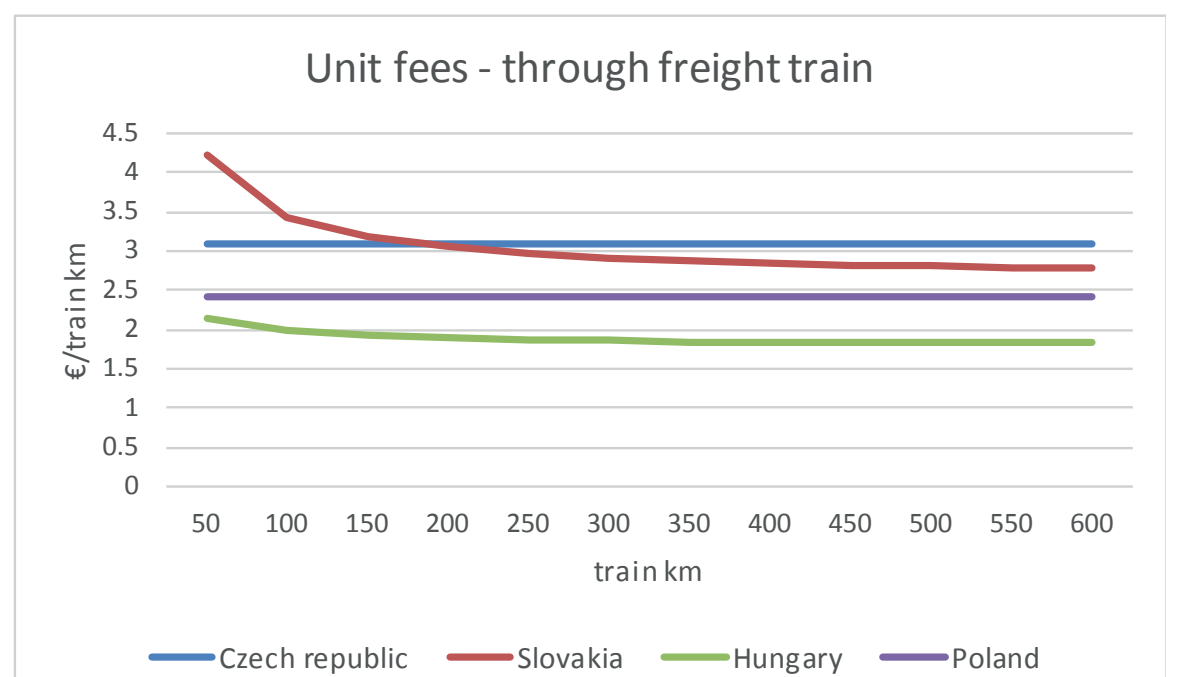

Figure 10 Unit fees the for rail infrastructure access for a through freight train in the first track category

Table 6 Total fees of the minimum access packages and access to services facilities in the 1. track category for a through freight train

\begin{tabular}{ccccccccc}
\hline \multirow{2}{*}{$\begin{array}{c}\text { gross } \\
\text { ton } \\
\text { of } \\
\text { train }\end{array}$} & \multicolumn{9}{c}{$200 \mathrm{~km}$} & $\begin{array}{c}\text { distance } \\
\text { Republic }\end{array}$ & Slovakia & Hungary & Poland & $\begin{array}{c}\text { Czech } \\
\text { Republic }\end{array}$ & Slovakia & Hungary & Poland \\
\cline { 2 - 9 } 300 & 169.109 & 312.649 & 236.762 & 194.928 & 422.16 & 662.95 & 565.48 & 590.84 \\
600 & 242.880 & 376.249 & 267.054 & 215.506 & 606.58 & 821.96 & 641.21 & 653.55 \\
900 & 349.585 & 439.850 & 297.345 & 286.173 & 873.36 & 980.96 & 716.94 & 849.98 \\
1200 & 487.906 & 503.451 & 327.636 & 329.093 & 1219.15 & 1139.96 & 792.67 & 980.79 \\
1500 & 556.408 & 567.051 & 357.928 & 374.701 & 1390.40 & 1298.96 & 868.39 & 1119.79 \\
1800 & 689.460 & 630.652 & 388.219 & 422.681 & 1723.03 & 1457.96 & 944.12 & 1266.02 \\
2100 & 752.692 & 694.252 & 418.510 & 468.793 & 1881.11 & 1616.96 & 1019.85 & 1406.56 \\
2400 & 887.061 & 757.853 & 448.802 & 329.093 & 2217.04 & 1775.97 & 1095.58 & 1544.54 \\
2700 & 951.611 & 821.454 & 479.093 & 557.804 & 2378.41 & 1934.97 & 1171.31 & 1677.84 \\
3000 & 1145.261 & 885.054 & 509.385 & 597.406 & 2862.54 & 2093.97 & 1247.04 & 1798.54 \\
\hline
\end{tabular}

As can be seen in Figure 9 and 10, the highest rail infrastructure access fees are in the Czech Republic (from $220 \mathrm{~km}$ distance). But if one takes into account the through freight train with lower fees for the gross tons (e. g. 300 gross tons) fees in the Czech Republic would be the cheapest as can be seen in Table 6 . That is caused by the rapid increase in specific factor $\mathrm{S} 1$ (formula (3)), which takes the train weight category into account. For the train's gross tons, 500 tons, $\mathrm{S} 1$ factor is 1.34 , for 2,000 tons is 5.37. The Slovak Republic has the highest charges for access to a train formation station which can be seen in the unit costs.

The total fees for the container train were compared, because some infrastructure managers (in the Czech Republic and Poland) use a specific factor for this train and the total fees are lower compared to the through freight train
Fees for a container train are the lowest in the Czech Republic because this country provide a direct discount on freight trains, which are operated as combined transport trains. This discount serves to support the development of this market segment and should therefore motivate carriers to use both the railway itself and use of various types of transport equipment, such as conventional containers, Innofreight container system etc. The infrastructure manager uses a product factor - P4 (formula (3)) for this discount, which has a rank of 0.65 . However, this discount does not apply to the total fee for the $\mathrm{Z}$ rail infrastructure, but to a fee for the running trains' track use. The rail infrastructure manager in Slovakia does not take any freight train segmentation, rail infrastructure manager in Hungary uses different rates dependent on gross tons for standard freight train and other trains. In Slovakia, 


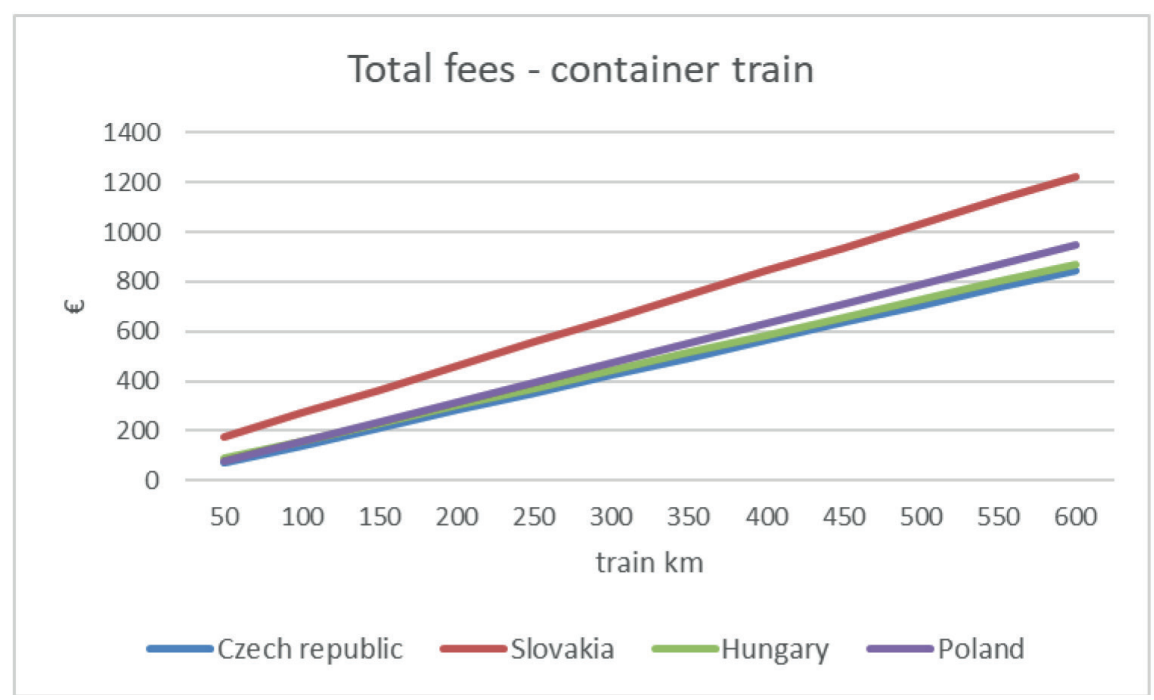

Figure 11 Total fees for the rail infrastructure access for a container train in the first track category

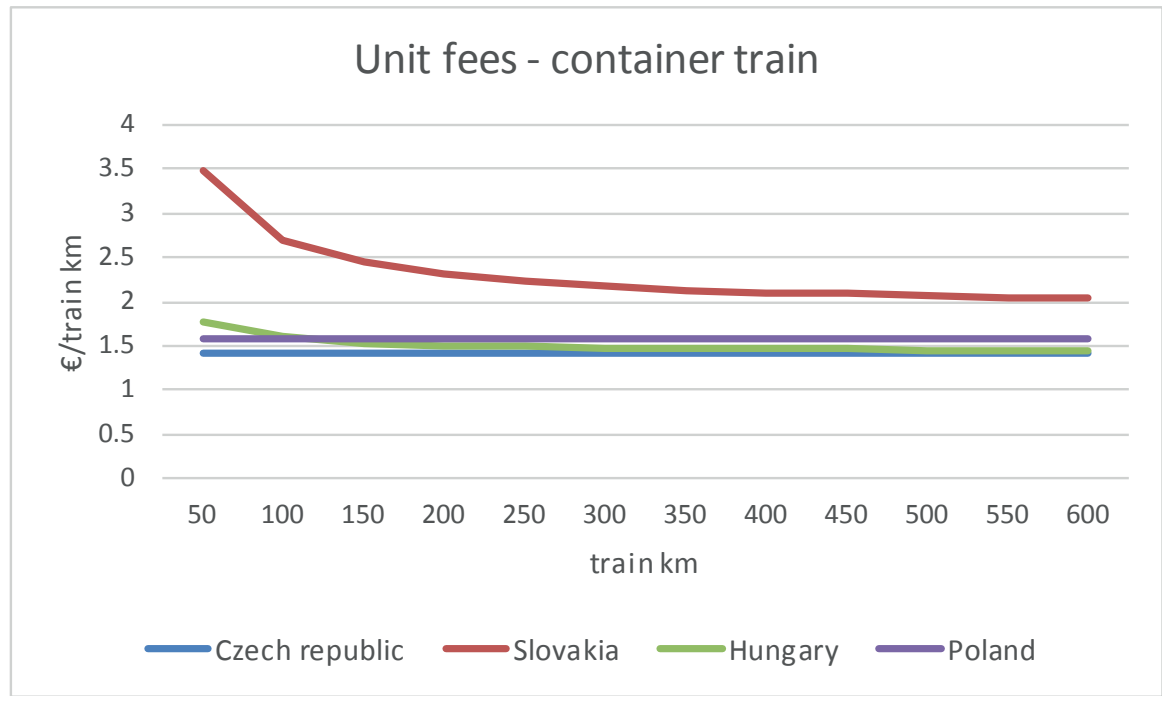

Figure 12 Unit fees for the rail infrastructure access for a container train in the first track category

the most expensive is access to train formation stations (more than three times that of Hungary) for that the unit fees are higher for $50 \mathrm{~km}$ distance and then fall rapidly.

\section{Discussion}

Charges for the railway infrastructure use are the important costs item of the rail passenger and freight carriers. Carriers must be able to calculate this fee in advance for a correct calculation of these costs to the product. In the case of international railway transport, the prices of the rail infrastructure services and mainly the system of rail infrastructure charges are different. Despite the fact that the train $\mathrm{km}$ and gross ton $\mathrm{km}$ are the main parameters which the fees depend on, the systems are very different.

Comparison of charges for use of the railway infrastructure, for different passenger and freight trains in different track categories, in the V4 countries, showed many interesting differences like:

- the cheapest fees for passenger train on the first track category are in the Czech Republic, the most expensive are in Slovakia;

- the results on the second and third track category are different, for example the fees for Passenger train in Slovakia is the cheaper than in Hungary;

- in the case of a freight train, there is a different situation in the Czech Republic compared to the other countries; the fees for the through train are the highest (approximately the same as in Poland), but for the container train are the cheapest.

This study and its results are limited by the premises of passenger and freight train introduced in sections 4.1 and 4.2 , as well as by the current Network Statement of the rail infrastructure managers in the $\mathrm{V} 4$ countries. In practice, there may be a change in the 
train set (for example, in the border's exchange station a locomotive can be changed), the number of train stops at the same distance is different, etc. Some countries change prices of individual rail infrastructure services every year (for the period of validity of the timetable) or change the system of rail infrastructure charges. However, for the purposes of the relevant comparison, not all the real factors (especially as far as the train parameters are concerned) can be taken into account, as the results would be distorted.

\section{Conclusions}

Achieving a single European railway area is a demanding and lengthy process. Besides the technical differences, there are many other differences, which complicate rendition of the rail passenger and freight services especially in international transport. One of these differences is the rail infrastructure charging system. Despite the fact that there is a common EU legal framework in the field of charges for the use of railway infrastructure, individual countries use different systems. The presented study shows that larger differences are for passenger trains.

In the case of passenger trains, it can be stated that in all the analyzed countries there is no difference in terms of rail infrastructure charges, whether it is an express train or a lower category train, such as a regional train. If the train category affects the price, then only assuming the use of different types of locomotive that have different weights, or whether the set uses dependent or independent traction, since in some countries (Slovakia, Hungary, Poland) the resulting price is less affected by charging the overhead contact line. However, it is necessary to mention that Slovakia adds the factor of train running independent traction on the line to the price, where an electric traction line is available at the same height, as a separate fee for locomotive dependent traction using this device. The final price in Slovakia, Czech Republic and Hungary is also affected by charging for use of the railway stations for passenger transport, which is a mandatory part of the rail infrastructure fees (as can be seen in tables 4 and 5). However, in the case of Slovakia, this part of the charge is a negligible amount of only a small amount of euros per train stop (in the case of regional train for distance $60 \mathrm{~km}$, difference is $58.788 €$ ). In this case, Hungary has the most expensive charge for use of the railway stations, which is, on average, $€ 7.03$ per stop.

There are many factors that affect the fees of the rail infrastructure use regarding the freight transport. Among the V4 countries, the Czech Republic uses the most possible factors that may affect the final price for infrastructure in its charging system. Their system is based on product and specific factors, which allows the segmentation of the fees by type of train, using level of ETCS (European Train Control System) and other factors comparable to other countries. The development of fees with regard to distance, is also significantly affected by the train's weight. While charges for the through freight trains with a lower weight are the lowest in the Czech Republic, for trains with a higher weight (more than 1,700 gross tons) they are the lowest in Hungary and in the Czech Republic are the highest (as can be seen in table 6). The situation is completely different when comparing international transport trains. Due to the fact that the Czech Republic uses a product factor that favors these trains, the fees are significantly lower than in Slovakia. When those charges on other categories of tracks, under approximately comparable conditions, were analyzed, it turned out that the differences in the level of charges among these countries were the same.

The current different charging systems increase the requirements on the distribution processes of carriers, especially when planning the new transports or comparing the costs of alternative routes, for example, in the case of insufficient railway infrastructure capacity. However, the unification of charging systems (not rates) is not a technical or economic problem, but rather a political problem.

\section{Acknowledgements}

The paper was supported by the VEGA Agency, Grant No. 1/0379/20 "Socio-economics aspects of rail transport market services deregulation in the context of EU legal framework and sustainable mobility", at Faculty of Operations and Economics of Transport and Communication, University of Zilina, Slovakia.

\section{References}

[1] Sustainable transport. An official website of the European Union [online]. 2020. Available from: https://ec.europa.eu/transport/themes/sustainable_en

[2] Going climate - neutral by 2050. A strategic long-term vision for a prosperous, modern, competitive and climate - neutral EU economy. Luxembourg: Publications Office of the European Union, 2019.

[3] Directive (EU) 2016/2370 of the European Parliament and of the Council of 14 December 2016 amending Directive 2012/34/EU as regards the opening of the market for domestic passenger transport services by rail and the governance of the railway infrastructure [online]. Available from: https://eur-lex.europa.eu/legal-content/ en/ALL/?uri=CELEX\%3A32016L2370 
[4] Directive 2012/34/EU DIRECTIVE 2012/34/EU of the European parliament and of the council of 21 November 2012 establishing a single European railway area [online]. Available from: https://eur-lex.europa.eu/legalcontent/EN/ALL/?uri=celex\%3A32012L0034

[5] JOHANSSON, P., NILSSON, J.-E. An economic analysis of track maintenance costs. Transport Policy [online]. 2004, 11(3), p. 277-286. ISSN 0967-070X. Available from: https://doi.org/10.1016/j.tranpol.2003.12.002

[6] WHEAT, P., SMITH, A. S. J. Assessing the marginal infrastructure maintenance wear and tear costs for Britain's railway network. Journal of Transport Economy and Policy. 2008, 42(2), p. 189-224. ISSN 0022-5258, eISSN 1754-5951.

[7] ANDERSSON, M. Marginal cost of railway infrastructure wear and tear for freight and passenger trains in Sweden. European Transport - Transporti Europei. 2011, 48, p. 3-23. ISSN 1825-3997.

[8] ODOLINSKI, K., BOYSEN, H. E. Railway line capacity utilisation and its impact on maintenance costs. Journal of Rail Transport Planning and Management [online]. 2019, 9, p. 22-33. ISSN 2210-9706. Available from: https://doi.org/10.1016/j.jrtpm.2018.12.001

[9] CALVO, F. J., DE ONA, J. DE ONA, R., LOPEZ, G., GARACH, L. A proposal for cost-related and marketoriented train running charges. Transportation Planning and Technology [online]. 2014, 37(4), p. 354-372. ISSN 0308-1060, eISSN 1029-0354. Available from: https://doi.org/10.1080/03081060.2014.897127

[10] ODOLINSKI, K. Estimating the impact of traffic on rail infrastructure. Journal of Transport Economics and Policy. 2019, 53, p. 258-274. ISSN 0022-5258, eISSN 1754-5951.

[11] SMITH, A., IWNICKI, S., KAUSHAL, A., ODOLINSKI, K., WHEAT, P. Estimating the relative cost of track damage mechanisms: combining economic and engineering approaches. Proceedings of the Institution of Mechanical Engineers Part F-Journal of Rail and Rapid Transit [online]. 2017, 231(5), p. 620-636. ISSN 09544097, eISSN 2041-3017. Available from: https://doi.org/10.1177/0954409717698850

[12] ROTOLI, F., VALERI, E., RICCI, S., RIZZETTO, L. An analysis of the railway access charges regime in the Italian context. Transport Policy [online]. 2018, 64, p. 20-28. ISSN 0967-070X, eISSN 1879-310X. Available from: https://doi.org/10.1016/j.tranpol.2018.01.006

[13] FRANKLIN, F., NEMTANU, F., TEIXEIRA, P. F. Rail infrastructure, ITS and access charges. Research in Transportation Economics [online]. 2013, 41(1), p. 31-42. ISSN 0739-8859. Available from: https://doi.org/10.1016/j.retrec.2012.10.004

[14] NASH, C. Rail infrastructure charges in Europe. Journal of Transport Economics and Policy. 2005, 39, p. 259-278. ISSN 0022-5258.

[15] GASPARIK, J., ABRAMOVIC, B., ZITRICKY, V. Research on dependences of railway infrastructure capacity. Tehnicki Vjesnik-Technical Gazette [online]. 2018, 25(4), p. 1190-1195. ISSN 1330-3651, eISSN 1848-6339. Available from: https://doi.org/10.17559/TV-20160917192247

[16] MASEK, J., KENDRA, M., CAMAJ, J. Model of the transport capacity of the train and railway track based on used types of wagons. In: 20th International Scientific Conference Transport Means 2016: proceedings. 2016. p. 584-588.

[17] OBERG, J., ANDERSSON, E., GUNNARSSON, J. Track access charging with respect to vehicle characteristics. 2. ed. Repport LA-BAN 2007/31, Banverket, 2007.

[18] SAVELSBERGH, M., TALEBIAN, M. Cost allocation under competition: a new rail access charging policy. Euro Journal on Transportation and Logistics [online]. 2019, 8(5), p. 511-534. ISSN 2192-4376. Available from: https://doi.org/10.1007/s13676-018-0133-z

[19] STENDARD, M., JAGRIC, T., ROSI, B. Estimating marginal infrastructure cost in new infrastructure charging model. Tehnicki Vjesnik-Technical Gazette [online]. 2018, 24(3), p. 829-836. ISSN 1330-3651, eISSN 1848-6339. Available from: https://doi.org/10.17559/TV-20160218095139

[20] TRAMPISCH, C. Track access charge control in the railway sector, its interaction with specific financing structures and the determination of incentives - the German infrastructure manager DB Netz AG. Review of Network Economics [online]. 2017, 16(2), p. 177-186. ISSN 2194-5993, eISSN 1446-9022. Available from: https://doi.org/10.1515/rne-2018-0015

[21] ABRAMOVIC, B. Infrastructure access charges. In: Sustainable rail transport [online]. MARINOV, M. (ed.). 2016. ISBN 978-3-319-58642-7, eISBN 978-3-319-58643-4, p. 45-58. Available from: https://doi.org/10.1007/978-3319-58643-4_4

[22] ALVAREZ-SANJAIME, O., CANTOS-SANCHEZ, P., MONER-COLONQUES, R., SEMPERE-MONERRIS, J. J. Rail access charges and internal competition in high speed trains. Transport Policy [online]. 2016, 49, p. 184-195. ISSN 0967-070X, eISSN 1879-310X. Available from: https://doi.org/10.1016/j.tranpol.2016.04.006

[23] TALEBIAN, M., SAVELSBERGH, M., MOFFIET, C. A new rail access charging policy: Hunter Valley coal chain case study. Transport Policy [online]. 2016, 46, p. 101-108. ISSN 0967-070X, eISSN 1879-310X. Available from: https://doi.org/10.1016/j.tranpol.2015.10.007 
[24] BUGARINOVIC, M., DIMITRIJEVIC, B., BOSKOVIC, B. The missing component in rail charging modelingaccess charges principle selection. International Transactions in Operational Research [online]. 2015, 22(5), p. 841-859. ISSN 0969-6016, eISSN 1475-3995. Available from: https://doi.org/10.1111/itor.12117

[25] CROZET, Y., CHASSAGNE, F. Rail access charges in France: beyond the opposition between competition and financing. Research in Transportation Economics [online]. 2013, 39, p. 247-254. ISSN 0739-8859. Available from: https://doi.org/10.1016/j.retrec.2012.06.021

[26] NIKOLOVA, CH. User charges for the railway infrastructure in Bulgaria. Transportation Research Part A-Policy and Practice [online]. 2008, 42(3), p. 487-502. ISSN 0965-8564. Available from: https://doi.org/10.1016/j. tra.2008.01.015

[27] DOLINAYOVA, A., CAMAJ, J. Rail infrastructure charges in the V4 countries. In: Road and Rail Infrastructure. In: 5th International Conference on Road and Rail Infrastructure CETRA 2018: proceedings. 2018. p. 917-923.

[28] KROL, M., TACZANOWSKI, J., JARECKI, S., KOLOS, A. Publicly-owned operators can also challenge incumbents. New cases of open-access passenger rail competition in Poland. Journal of Rail Transport Planning and Management [online]. 2019, 12, 100150. ISSN 2210-9706, eISSN 2210-9714. Available from: https://doi. org/10.1016/j.jrtpm.2019.100150

[29] ERDOS, A. K. Enhancing the competitiveness of passenger railway markets. Procedia Economics and Finance [online]. 2014, 12, p. 138-143. ISSN 2212-5671. Available from: https://doi.org/10.1016/S2212-5671(14)00329-3

[30] PITMAN, R., JANDOVA, M., KROL, M., NEKRASENKO, L., PALETA, T. The effectiveness of EC policies to move freight from road to rail: evidence from CEE grain markets. Research in Transportation Business and Management [online]. 2020, 37, 100482. ISSN 2210-5395. Available from: https://doi.org/10.1016/j. rtbm.2020.100482

[31] Network statement for timetable 2019/2020 - ZSR [online]. Available from: https://www.zsr.sk/files/ dopravcovia/zeleznicna-infrastruktura/podmienky-pouzivania-zel-infrastruktury/network-statement-2020/ networkstatement_2019-2020_amendment_1.pdf

[32] Network statement on the nationwide and regional railways 2020 - SZDC [online]. Available from: https://www. spravazeleznic.cz/documents/ 50007830/51603092/ Network+Statement+2020_2amendment.pdf/209553bb972a-4c40-9637-1392d1e00205

[33] Network Statement MAV, 2020. Online. Available at: https://www2.vpe.hu/eng/network-statement/networkstatement-2019-2020

[34] Network statement PKP 2019/2020. Annex 12 Price list of of fees for using the $1435 \mathrm{~mm}$ track gauge railway infrastructure managed by PKP - Polskie Linie Kolejowe s.a. [online]. Available from: https://en.plksa. pl/files/public/user_upload/pdf/Reg_przydzielania_tras/ Regulamin_sieci_2019_2020/Zal_12_Reg19_20_v10_ Pricelist1435.pdf

[35] Eurostat 2019. GDP - Purchasing power parities (PPPs), price level indices and real expenditures for ESA 2010 aggregates [online]. Available from: https://ec.europa.eu/eurostat/data/database

[36] ECB foreign exchange reference rates [online]. 2020. Available from: https://www.nbs.sk/en/statistics/exchangerates/ecb-foreign-exchange-reference-rates 